\title{
Impact of Pranayama on Fine Moter Coordination Ability of Children with Intellectual Impairment
}

\author{
Sunita Singh*, Jay Prakash Singh \\ Faculty of Education, Banaras Hindu University, Varanasi, India \\ Email: ${ }^{*}$ sunitasingh.bhu@gmail.com
}

Received 19 June 2013; revised 19 July 2013; accepted 5 August 2013

Copyright (C) 2014 by authors and Scientific Research Publishing Inc.

This work is licensed under the Creative Commons Attribution International License (CC BY). http://creativecommons.org/licenses/by/4.0/

(c) (i) Open Access

\begin{abstract}
Approximately $2.5 \%$ to $3 \%$ of the children are intellectually impaired who lack fine motor coordination abilities like eye-hand coordination, grip strength in fingers, etc. There is a need to improve their condition for better survival. Pranayama has been found to be very effective in the case of general children in the development of these abilities. But there is very little study on the application of pranayama practice for children with intellectual impairment. In the present five mild intellectually impaired children of age ranges 7 - 10 years practiced the pranayama for 60 days. The performance of all children shows significant difference at 0.01 levels at 20 degree of freedom for the "inserting pegs task" developed by Indian Medico Instruments. It indicates the pranayama in an effective way to improve the fine motor coordination ability among children with intellectual impairment.
\end{abstract}

\section{Keywords}

Pranayam; Intellectual Impairment Children; Motor Coordination

\section{Introduction}

Intellectual impairment means significantly sub-average general intellectual functioning, which exists concurrently with depicts in adaptive behavior and manifested during the developmental period that adversely affects a student's educational performance. It affects a child's ability to reason and understand, to acquire skills and master developmental milestones within "typical" age range, to solve problem and adapt to new situations, and to learn and remember as easily as others.

*Corresponding author. 
Children who are intellectually impaired function at an intellectual level that is below average and have difficulties with learning and daily living skills. Conceptual skills like language, social skills like interaction with others and practical skills like self-care are lacking in children with intellectual impairment. Children labeled as such need special care to overcome social, intellectual and physical disabilities.

Children with intellectual impairment generally lack fine motor coordination abilities (Panda, 1997). There are so many techniques and methods to develop fine motor co-ordination abilities like rolling play dough into tiny balls (Peas) using only the finger tips, using pegs or toothpicks to make designs in play dough, tearing news paper into strips and then crumpling them into balls, scrunching up one sheet of newspaper in one hand, using small sized screwdrivers like those found in an erector set.

All these methods are merely based on training. They generally take longer duration to develop fine motor co-ordination abilities. Moreover, they require special educator and adopted materials. Special educator follows all the techniques and adapted material to train the children with impairment following the proper teaching strategies so as to train them effectively.

Yoga is one of the important methods to improve the fine motor coordination ability among children. The great Indian philosopher Patanjali Maharshi describes Yoga in his Yoga Sutra as "chittavrittinirodha" i.e. cessation of the fluctuation of mind. According to him, Yama (abstention), Niyama (observance), Asana (posture) Pranayama (life force control), Pratyahara (abstraction), Dharana (concentration), Dhyana (meditation) and Samadhi (liberation) are the eight stages or limbs of yoga. Pranayama "prana" + "yama" is the fourth limb of yoga which balances nervous system and improves mental clarity and physical coordination (Chanchani \& Chanchani, 2006).

Yoga training increases the grip strength, dexterity, confidence, self-efficiency, mental health, creativity, concentration, memory \& intellectual abilities. Yogasana reduces neurotic tendency, general anxiety, and physiological anxiety \& sleep disturbance (Venkatesh, 2005). Crowley (2002) found that if brief yoga programme organizes that, the immediate anxiety level will reduce. Yoga improves the quality of life and self-esteem (Deshpande, 2008). Yogasanas may be helpful in improving the memory span of children with intellectual impairment. Breathing exercises, Pranayama, Sithilikaranavyayama, Suryanamaskar, Yogasanas \& Meditation improve the IQ and social adaptation of mental retarded children (Uma et al., 1989). The findings of Manjunath \& Telles (2004) study indicate that Yogasanas \& Yoga breathing increase the delayed recall of spatial information. There are so many Yogasanas. In the present research paper, only one asana i.e. Pranayam has been taken.

Pranayama can have a massive calming effect on children who practice it, calming negative excitable behaviour. It can also help children to develop a stronger memory, will power, higher levels of concentration and improved respiration (Rawat, 2005). There are so many studies (Desikachar, 1987; Jayachandran, 1998) related to the improvement of fine motor skills, but none of them tried to find out the impact of pranayama on coordination abilities for the children with intellectual impairment.

\section{Statement of the Study}

“Impact of Pranayama on Fine Motor Coordination Ability of Children with Intellectual Impairment.”

\section{Objectives of the Study}

- To develop some activities related to pranayama to teach children with intellectual impairment.

- To study the impact of pranayama practice on fine motor coordination among children with intellectual impairment.

- To study the significant differences if any in the fine motor activities (eye-hand coordination, hand-to-hand coordination, etc) of children with intellectual impairment undergone pranayama practice.

\section{Hypothesis}

- There is significance difference in the inserting pages task performed by children with intellectual impairment before and after pranayama practice.

\section{Methodology}

Being experimental in nature, it was designed on the lines of pre-test, post-test. 


\subsection{Population and Sample}

Children with mild intellectual impairment studying in various mentally retarded primary level schools of Tamil Nadu and age-group 7 - 10 years were the population of the present study. Five children were selected through purposive random sampling technique. These children are as follows:

$\begin{array}{lll}\text { Sandil K. } & - & \text { Autism } \\ \text { Murali R. } & - & \text { ADHD } \\ \text { Shakti G. } & - & \text { ADHD + Over protection } \\ \text { Sabish M. } & - & \text { Down's Syndrome } \\ \text { Harsha V. } & - & \text { Down's Syndrome }\end{array}$

\subsection{Tool Used for the Study}

Peg board having ten sticks and sixty pegs for “inserting pegs task” developed by India Medico Instrument (Occupational Therapy Equipments) was used to measure the fine motor coordination abilities among the children with intellectual impairment.

\subsection{Pre-Tryout for the Tool Used}

The peg board selected for the study was first administered on ten normal children. These children performed very well in the instructed task. After that the same peg board was administered on two children with intellectual impairment. They also performed the task successfully but took more time. On this basis the peg board task was administrated on the subjected for the present study.

\subsection{Collection of Data and Experimentation}

Single subject research design was used in this study. In this research design, there was only experimental group of five children with intellectual impairment. Before collection the data, the researchers established the report with the children. The pre-test was administered on the experimental group. The performance of these children on peg board task was measured in terms of time taken (in seconds).

After the pre-test, the investigator started the practicing pranayama "Onkar” chanting was practiced for five times, after sitting in the Dhyan Mudra. The same was repeated for five days. Then, the investigator practiced the left nostril breathing for 10 minutes and right nostril breathing also for 10 minutes. After that the children were instructed the chant "Omkar” by keeping their fingers on the closed eye-lids, “Omkar" was chanted by closing the ears with the palm. Lastly, the children had to mediate for 5 minutes. The aforesaid pranayama practice was repeated was for 60 days. After that the same tool (peg board) was again administered for the post-test. In this test also the number of trials given to each child was 20. Comparison of their performance was done by the average time taken (in second) in the completion of task in pre-test and post-test.

\section{Analysis and Interpretation}

“t”-Test was used as differential analysis. The graphical representation of the average time taken in pre-test and post-test has also been presented by bar graphs in separate colours for each child.

It is clear from the Table 1 and Figure 1 that:

1) In the inserting pegs task performed by autistic child, the obtained " $\mathrm{t}$ " value 4.86 is greater than the theoretical value of 1.72 at 20 degree of freedom at 0.01 level of significance. There, it can be concluded that there is significant difference between mean/average time taken $156.35 \mathrm{sec}$ and $145.75 \mathrm{sec}$. in pre test and post-test. The autistic children have average or above average intelligence, poor coordination and concentration, limited range of interests, do things or say things over and over again.

2) ADHD children have very weak attention span and coordination as well as easily distracted and have low level of tolerance. The second and third children performed the inserting pegs task with the obtained " $\mathrm{t}$ " values 3.65 and 6.43 respectively which are greater than the theoretical value of 1.72 at 20 degree of freedom at 0.01 level of significance. There are significant differences in the mean/average time taken in the pre-test and the post-test.

3) For Down’s syndrome children (slow motor development, poor coordination, significantly delayed language 
Table 1. Comparison of mean/average time taken \& standard deviation in pre-test and post test, standard error and t-value.

\begin{tabular}{|c|c|c|c|c|c|}
\hline \multicolumn{6}{|c|}{ Number of Trails- 20} \\
\hline Subject & Test & Mean/Average Time Taken (in second) & Standard Deviation & Standard Error & t-value \\
\hline \multirow[t]{2}{*}{ Sandil K. } & Pre-Test & 156.35 & 7.48 & \multirow{2}{*}{2.18} & \multirow{2}{*}{$4.86^{*}$} \\
\hline & Post-Test & 145.75 & 6.24 & & \\
\hline \multirow[t]{2}{*}{ Murali R. } & Pre-Test & 310.90 & 15.31 & \multirow{2}{*}{3.96} & \multirow{2}{*}{$3.65^{*}$} \\
\hline & Post-Test & 296.45 & 8.95 & & \\
\hline \multirow[t]{2}{*}{ Shakti G. } & Pre-Test & 145.05 & 7.78 & \multirow{2}{*}{2.21} & \multirow{2}{*}{$6.43^{*}$} \\
\hline & Post-Test & 130.85 & 6.08 & & \\
\hline \multirow[t]{2}{*}{ Sabish M. } & Pre-Test & 345.85 & 9.24 & \multirow{2}{*}{3.24} & \multirow{2}{*}{$6.06^{*}$} \\
\hline & Post-Test & 319.75 & 11.14 & & \\
\hline \multirow[t]{2}{*}{ Harsa V. } & Pre-Test & 225.35 & 5.94 & \multirow{2}{*}{1.71} & \multirow{2}{*}{$6.13^{*}$} \\
\hline & Post-Test & 211.45 & 4.82 & & \\
\hline
\end{tabular}

*Significant at 0.01 level.

Av. Time Taken (in Sec.)

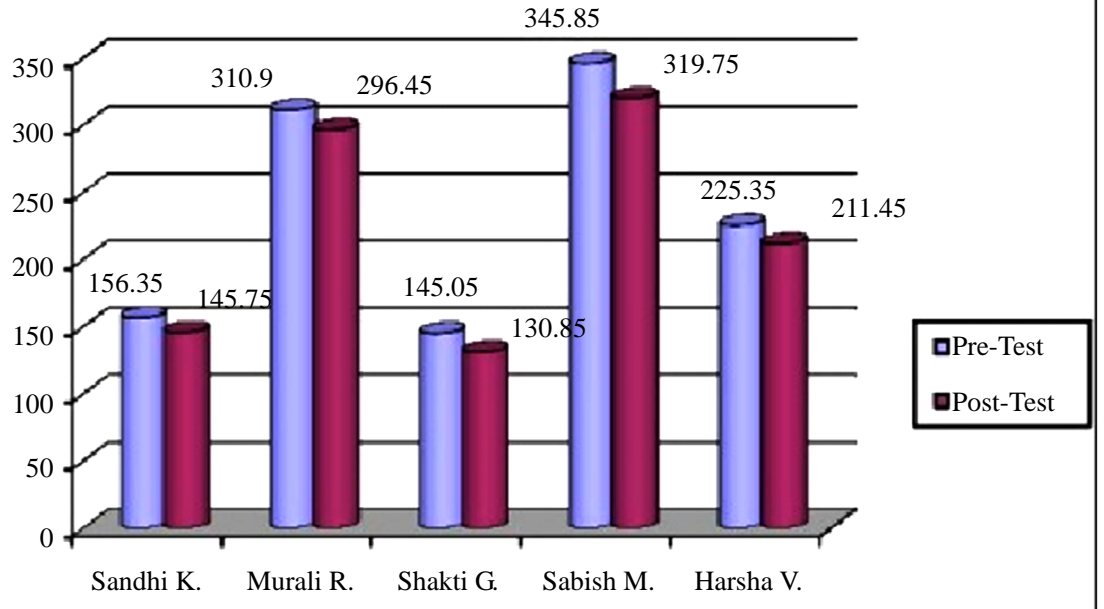

Subject

Figure 1. Average time taken (in second) to complete the task by different subjects.

and cognitive development, etc), the obtained t-values in performing pegs task are 6.06 and 6.13 respectively. These values are greater than the theoretical t-value of 1.72 at 20 degree of freedom at 0.01 level of significance. Therefore, there are significant differences between mean/average time taken in performing the inserting pegs task in pre-test and post-test.

\section{Findings}

1) In the inserting pegs task performed by the autistic child, there is significant difference before and after pranayama practice. It is significant at 0.01 level of 20 degree of freedom.

2) There is significant difference in the inserting pegs task performed by the ADHD child before and after 
pranayama practice. The level of significance is 0.01 and degree of freedom is 20 .

3) Difference in the performance of the inserting pegs task by the ADHD child with over-protection before and after pranayama practice is significant at 0.01 levels. Degree of freedom is 20 .

4) In the inserting pegs task, at the 0.01 level of significance at 20 degree of freedom, there is significant difference in the performance of the Down's syndrome child before and after pranayama practice.

\section{Conclusion}

Yogasana is based on a sound knowledge of human anatomy and physiology. Placing the body in certain posture or position stimulates specific nerves, organs and glands. Many yogasanas offer an opportunity for the physical expression of mental imagery, with which children are usually very comfortable. Sitting yogasanas provide greater blood circulation in parts above the waist. Thus, the vital organs are energized, giving increased stimulus to brain functioning. Similarly, inverted yogasanas help in increasing blood flow to the brain and activate the brain cell. So, yogasanas may be helpful in improving fine motor coordination of children with intellectual impairment. Yoga training also increases the grip strength, dexterity, confidence, self-efficiency, mental health, creativity, concentration, memory \& intellectual abilities.

In the present study, the researcher has selected yogasana for a practice session, which might influence the blood circulation to the brain region. Main yogasana is pranayam. The autistic children have average or above average intelligence, poor coordination and concentration, limited range of interests, and do things or say things over and over again. The performance of the first child indicates that the pranayama practice can improve his weaknesses. From this it could be inferred that pranayama is effective in bringing improvement in the focus and concentration for the particular task as well as body awareness.

In ADHD children, pranayama might calm the mind and help in the increment of attention span. It may also purify and remove distractions from the mind. Due to this reason, children showed improvement after the pranayama practice. Pranayama may improve the functions of the brain cells which may result in the improvement of memory and concentration. It may also improve the finger flexibility and grip strength. So, we can say that difference in the performance of these children is due to pranayama practice. Yogasana reduces neurotic tendency, general anxiety, and physiological anxiety \& sleep disturbance (Venkatesh, 2005). Result of the present study is also supported by the work of earlier studies. On the basis of the result, it may be concluded that pranayama increases the fine motor coordination ability of children with intellectual impairment.

\section{Implications}

- The findings of the present study are helpful for special educators. The special educators can introduce some of breathing exercises for the children with intellectual impairment that will help to bring the autistic child out of his shell (self). This helps to promote social interaction. Pranayama will strengthen that child's concentration and body awareness.

- Pranayama is one of the best ways to start working children with ADHD. Special educator will help to treat a child by introducing breathing exercises and a few poses before attempting to teach them an entire yoga routine. This will help them to calm down enough to follow instructions. Alternate nostril breathing will be of a particular benefit to children with ADHD because it can help to calm the mind. With a regular pranayama practice, children with ADHD can develop a greater body awareness and concentration-increasing their capacity for schoolwork and creative play.

- Pranayama can be very effective technique in the reduction of odd behaviour of Down's syndrome children. The findings of the present study also support this for fourth and fifth children. Pranayama may increase their concentration. It will be helpful not only for physical health but also mental health. It will enhance the sitting tolerance of the children with Down's syndrome.

\section{References}

Chanchani, S., \& Chanchani, R. (2006). Yoga for Children. New Delhi: Student Book Depot (Publishers).

Crowley, A. (2002). The Psychological and Physiological Effects of Yoga on Children. MA Thesis, Hawthorn, VIC: Swinburne University of Technology.

Deshpande, S. (2008). Influence of Yoga on Quality of Life: A Control Study. Ph.D. Thesis, Bangalore: Swami Vivekananda 
Yoga Anusandhana Samsthana.

Desikachar, T. K. V. (1987). The Yoga of T. Krishnamacharya. Madras: Krishnamacharya Yoga Mandiram.

Jayachandran, P. (1998). Yoga and Physical Training for the Mentally Retarded. The 6th Annual Seminar on Changing Perception on Mentally Retarded, Gwalior.

Manjunath, N. K., \& Telles, S. (2004). Spatial and Verbal Memory Test Scores Following Yoga and Fine Arts Camps for School Children. Indian Journal of Physiology and Pharmacology, 48, 353-356.

Panda, K. C. (1997). Education of Exceptional Children. New Delhi: Vikas Publishing House.

Rawat, G. (2005). Yoga: The Health Mantra. New Delhi: Student Book Depot.

Uma, K., Nagendra, H. R., Nagarathna, R., Vaidehi, S., \& Seethalakshmi, R. (1989). The Integrated Approach of Yoga: A Therapeutic Tool for Mentally Retarded Children: A One Year Controlled Study. Journal of Intellectual Disability Research, 33, 415-421. http://dx.doi.org/10.1111/j.1365-2788.1989.tb01496.x

Venkatesh, M. (2005). The Effect of Yoga on the Personality Development of Students. Ph.D. Thesis, Bangalore: Swami Vivekananda Yoga Anusandhana Samsthana. 